371.3:811.163.41

811.163.41'373.7

https://doi.org/10.18485/kij.2020.67.2.10

БОЈАНА Д. ТОДИЋ САНКОВИЪ

Оригинални научни рад

Институт за српски језик САНУ

Примљен: 12.11.2020.

Београд

Прихваћен: 14.12.2020.

\title{
ФРАЗЕОЛОГИЈА У НАСТАВИ СРПСКОГ ЈЕЗИКА: МОГУЋНОСТИ ШИРЕ ПРИМЕНЕ**
}

\begin{abstract}
У раду је реч о могућностима шире примене фразеолошког садржаја у основношколској и средњошколској настави српског језика. Будући да садржаји из области фразеологије нису у одговарајућој мери заступљени у наставном плану и програму, главни циљ нашег рада јесте да се укаже на његове различите домене, који се могу даље осмишљавати као уже наставне јединице. Пажња у овом раду, с обзиром на његов практични карактер, усмерена је на одговарајуће типове задатака који прате сваку од издвојених подтема, у циљу што функционалније обраде датих фразеолошких сегмената. Показује се да се богата фразеолошка тематика може укључивати у различите наставне теме (попут наставе књижевности, стилистике, граматике, лексикологије), као и да се може оформити читав наставни блок посвећен фразеологији српског језика. Уз то, систематизована настава фразеологије оставља наставницима доста простора за подстицање развијања језичке и речничке културе ученика.
\end{abstract}

Кључне речи:фразеологија, настава српског језика у основним и средњим школама, наставни план и програм, могућности шире примене фразеолошке тематике у настави.

\section{1. Увод}

Фразеологија, као веома разноврсна и комплексна језичка област, оставља доста простора за различите истраживачке задатке али и за различите приступе у школској настави српског језика. Међутим, ни у основношколском ни у средњошколском образовању нису наставним планом и програмом јасно дефинисани, нити у одговарајућој мери заступљени, садржаји из области фразеологије. ${ }^{1}$ Упркос томе, тестови са такмичења из српског језика бележе питања која

*bojana.todic@isj.sanu.ac.rs

** Овај рад финансирало је Министарство просвете, науке и технолошког развоја Републике Србије према Уговору број 451-03-68/2020-14/200174 који је склопљен са Институтом за српски језик САНУ.

${ }^{1}$ Фразеолошке теме, према плану и програму, обрађују се у седмом разреду основне и у четвртом разреду средње школе. 
превазилазе програмске оквире заступљености фразеолошке тематике у наставној пракси.

Имајући у виду практичну примену фразеолошког садржаја у настави, као и његов могући утицај на иновирање наставног плана и програма, главни циљ нашег рада јесте да се укаже на различите домене богате фразеолошке тематике, који се могу даље осмишљавати као уже наставне јединице. ${ }^{2}$ Приступ за који смо се определили омогућио би наставницима да искористе своју креативност приликом уобличавања фразеолошких наставних јединица, али и ученицима да продру у основне принципе ове научне дисциплине, што би унапредило и њихова знања из језичке културе и културе изражавања.

Такође, пажњу у овом раду, с обзиром на његов практични карактер, усмерили смо на одговарајуће типове задатака који прате сваку од издвојених подтема, у циљу функционалније обраде датих фразеолошких сегмената. ${ }^{3}$ На тај начин, професорима је омогућено, између осталог, и да ученике подробније упуте у задатке који се могу јавити на такмичењима из српског језика, и то кроз фразеолошке партије које могу бити савладане током редовне или додатне наставе.

\section{2. Фразеологија у настави српског језика}

\section{1. Увод у фразеологију: основни појмови}

\subsection{1. ТЕОРИЈСКИ ДЕО}

Приликом увођења термина и појма фразеологизам ${ }^{4}$ у наставу полазимо од његовог препознавања у тексту (в. вежбање 1). За потребе основношколске наставе наводимо једноставнији тип текста, где се могу лако уочити фразеологизми, који, с друге стране, морају бити општепознати, будући да се од ученика тражи да их интуитивно препознају, па чак и да, на основу свог језичког осећања, наслуте њихово значење.

2.1.1.1. Увод у фразеолошку тематику у основној и средњој школи треба да обезбеди уочавање и разумевање три основне особености фразеологизама: (1)да читав фразеологизам има једно, јединствено значење, које не одговара простом збиру значења речи које га чине; (2) да фразеологизми имају сложену структуру,

${ }^{2}$ Рад, у скраћеном виду, прати садржај радионице Фразеологија у настави српског језика $u$ кьижевности: могућности шире примене, одржане од стране аутора рада на 61. Републичком зимском семинару (7-9. 2. 2020. г.) на Филолошком факултету Универзитета у Београду.

${ }^{3}$ Радионица, чији су главни делови овде представљени, резултат је ауторовог рада и менторства у оквиру лингвистичке секције - Жаргонизми, фразеологизми и дијалектизми у односу на стандардни језик - на семинару у Образовно-културном центру „Вук Караџић” у Тршићу у протекле две године.

${ }^{4}$ У литератури су у равноправној употреби термини: идиом, идиоматска фраза, устаљена фраза, фразеолошки израз (обрт, конструкиија), устаљени обрт (конструкција), фразем, фразеологизам и фразеолошка јединица (Мршевић-Радовић 1987: 11). У овом раду ће бити коришћена потоња два. 
односно да се састоје од најмање две речи; као и (3) да имају устаљену структуру, односно да је поредак речи у фразеологизму донекле устаљен (Мршевић-Радовић 1987: 13; Станојчић, Поповић 2012: 203).

2.1.1.2. На прве две особености лако се може указати приликом вежбања на тексту. Лакши вид задатка, који има за циљ препознавање структурних и семантичких особености фразеологизама, може захтевати табеларно повезивање датог фразеологизма са претпостављеним значењем (в. вежбање 2). Средњошколцима, који су на часовима лексикологије упознати са термином и појмом полисемије, могу се понудити различите реченичне реализације, с захтевом да се у њима препозна фразеологизам (в. вежбања 4 и 5).

2.1.1.3. Кад је реч о трећој особености, ученицима ваља указати на то да су фразеологизми јединице које се (готово) увек употребљавају с истим распоредом компонената које га чине (в. Станојчић, Поповић 2012: 203). ${ }^{5}$ С тим у вези, задатак може бити постављен тако да на основу датих конструкција са измењеним члановима треба препознати о којим је фразеологизмима реч (в. вежбање 3). У средњошколској настави може се, кроз навођење типичних говорних ситуација, дискутовати и о значењу ових јединица.

\subsection{2. ДОДАТНА НАСТАВА}

Анализа такмичарских текстова за основне и средње школе коју је спровела М. Ђукић (2017) показала је да се међу такмичарским задацима јављају и они у којима се од ученика очекује да препознају разлику између фразеологизама и сличних појмова - термина и клишеа. Ова проблематика подразумева да се у (додатну) наставу укључе теоријска образложења сваке од наведене три јединице, уз указивање на основне разлике, те уз пригодна вежбања у којима би се те јединице препознавале и разграничавале (в. вежбања под 6 и 7). ${ }^{6}$

2.1.2.1. Прво, термини (терминолошке синтагме) слични су фразеологизмима због своје сложене структуре и општег (глобалног) значења. Међутим, за разлику од фразеологизама, они се не одликују експресивном функцијом (Мршевић-Радовић 1987: 20-21). Термин, као научно или стручно име за одређени појам, мора бити лишен сваке експресивности, која је, с друге стране, карактеристична за фразеолошке јединице.

2.1.2.2. Друго, клишеи (стереотипни изрази) приближавају се фразеологизмима јер представљају устаљене лексичке јединице, обично настале по утврђе-

${ }^{5}$ Тако можемо рећи Он је нечија слика и прилика, али не и Он је нечија прилика и слика, бар не са истим значењем, будући да фразеологизми не трпе преобликовање.

${ }^{6}$ У приручнику СЈКТ 2 (2008: 262-263) јавља се (неретко) следећи тип питања:

1 У реченици Преузете су неоходне мере и акције да би се спречиле негативне тенденције подвучени изрази су: а) фразеологизми; б) клишеи; в) термини.

Заокружи слово испред тачног одговора.

2 Подвучени израз у примеру Вршимо услуге пуњења плинских боца јесте:

а) бирократски клише; б) термин; в) разговорни фразеологизам.

Заокружи слово испред тачног одговора. 
ном обрасцу. Међутим, за разлику од фразеологизама, они су углавном знак бирократизације текста, потпуне шаблонизације исказа и, као такви, учестало се употребљавају у одређеној врсти текстова - административним и новинским (исп. Ђукић 2017: 240).

\subsection{3. ВЕЖБАЮА}

1. У следећем тексту подвуци фразеологизме:

Пре неки дан сам се провео као бос по трњу! Знао сам да ћу морати да засучем рукаве, али нисам очекивао да ће ме најбољи друг поново оставити на цедилу. Када је сав посао око заједничког домаћег задатка свалио на моја леђа, решио сам да мућнем главом и не дозволим да ме мота око малог прста! Рекао сам му да мора да схвати да ме не може више вући за нос. Тражио је да му опростим што ме је избацио из такта, а ја сам тешка срца одлучио да му и овај пут прогледам кроз прсте.

2. Повежи фразеологизме са њиховим значењем:

изнети (нешто) на сунце

ухватити (некога) за гушу

ослободити се бремена

довити се своме јаду

скинути копрену (с нечега) породити се, донети бебу на свет

обелоданити, обнародовати нешто

схватити о чему се ради

открити, разоткрити тајну

извршити притисак на некога

3. Препознај о којим је фразеологизмима реч и напиши како треба да гласе:

(a) бацати на некога гранчице и каменчиће бачати на некога дрвље и камене значење: „оштро нападати, критиковати обично претерано, незаслужено”

(б) ни бубу не би згазио ни мрава не би згазио значење: „никоме не би учинио ни најмање зло”

(в) смејати се као здрав на млеко смејати се као луд на брашно значење: „смејати се без разлога; смејати се неконтролисано”

(г) сравнити са водом_равнити са земљом значење: „потпуно уништити, разорити до темеља"

4. Заокружи слова испред реченица у којима постоји фразеологизам са речју крв: ${ }^{7}$

7 Задатке овог типа најзахвалније је састављати коришћењем описних речника српског језика у којима су, под скраћеницом Изр., забележени и примерима потврђени фразеологизми - Речник $C A H У$ или Речник MC. Међу бројним фразеологизмима наставник треба изабрати најфреквентније и укључити их у различите вежбе, с циљем спознавања њихове семантике и употребе (исп. Новокмет, Богдановић 2015: 182).Такође, оваква вежбања су захвална и за рекапитулацију претходно савладаног градива полисемије путем указивања на конкретне разлике међу лексемама употребљеним у секундарним значењима и у фразеолошким конструкцијама. 
(a) Најгоре је остати слеп код очију, јер те онда узјашу, сисају крв на памук.

(б) Он ми је једини род по крви на овоме свијету.

(в) Тај официр је говорио да нико не треба да жали ни своју ни непријатељску крв.

(г) Тај га је увриједио до крви, кад је за двије кривотворене исправе тврдио да су сумњиве.

5. Заокружи слово испред реченице у којој је употребљен фразеологизам са речју око:

(a) Игра тих очију привлачила је сву пажњу слушалаца.

(б) Била је у хаљини од златна ткања, на коју су везена ока паунових пера.

(в) На неке грешке у градњи чланови комисије зажмуре на једно око.

6. Следеће синтагме разврстај на терминолошке и фразеолошке:

неодређени вид, крупна риба, скочни зглоб, медвеђа услуга, пасје време, глаголски вид, ватрено крштење, средња вредност, црна овца, плућно крило, тениски лакат, страна света, речно дно, атомски број, најбоље године, кратак спој, подземне воде.

7. Међу следећим изразима подвуци фразеологизме (/Следеће изразе разврстај на клишее, термине и фразеологизме):

сатерати у мишју рупу, лични доходак, млатити празну сламу, водити битку за боље сутра, вишак вредности, задати ударац инфлацији, шпанско село, дивља јагода, коњска снага.

\section{2. Структура и значење фразеологизама}

\subsection{1. ТЕОРИЈСКИ ДЕО}

2.2.1.1. Настава граматике, предвиђена за обраду у каснијим разредима основне школе и у средњошколској настави, може укључивати и осврт на структурне особености вишечланих јединица какве су фразеологизми. ${ }^{8}$ У оквиру такве (прикључене или издвојене) наставне јединице ученицима треба представити основне структурне типове фразеологизама.

Једна од категоријалних особина фразеологизма као више лексемног споја јесте сложеност структуре. Међутим, због релативне структурне устаљености, уз коју често иде и варијантност једне или више компонената фразеологизма, није увек лако успоставити структурне типове ових јединица.

Према традиционалној структурној подели (исп. Вуловић 2015: 79-84; Мршевић-Радовић 1987), издвајају се следећа три општа структурна типа:

(1) предлошко-падежни: испод жита, до голе коже, на прву лопту, од Кулина бана, на крај света, у крајњој линији, до миле воље итд.;

\footnotetext{
${ }^{8}$ Ова тема погоднија је за средњошколце, али се може прилагодити и основношколској настави.
} 
(2) синтагматски: Ахилова пета, дрвени адвокат, леп као слика, мршав као грана, блед као крпа, гледати као теле у шарена врата, седети као на иглама, пушити као Турчин и сл.;

(3) реченични: фали/недостаје некоме даска у глави, кад на врби роди грожђе, кад је бог по земьи ходао, нису му (јој и сл.) све овие на броју, где је и бог (враг) рекао лаку ноћ, душа му (јој и сл.) је у носу и сл. ${ }^{10}$

Вежбања за утврђивање градива могу захтевати од ученика структурну анализу конкретних фразеологизма (као у вежбању 11) или пак разврставање фразеологизама према структурном типу (в. вежбања 9 и 10). Поред тога, од ученика се у посебном задатку може тражити да допишу структурни члан (или структурне чланове) фразеологизма који недостаје (в. вежбање 12$).{ }^{11}$

2.2.1.2. Поред структурне класификације фразеологизама, ученицима ваља указати на још једну могућност поделе, која се базира на међуодносу структурних и семантичких особености. Циљ такве анализе јесте да се утврде однос и облик везе значења читаве јединице и њене граматичке структуре. С тим у вези, према начину распоређивања општег фразеолошког значења језичке јединице у односу на њену сложену структуру, фразеологизми се деле на: (1) глобалне и (2) компонентне (в. Мршевић-Радовић 1987: 63-113).

Код првог типа јединица опште значење фразеологизма се изражава јединицом у целини. Другим речима, све компоненте фразеологизма учествују у формирању општег, глобалног значења (нпр. ушао му (joj и сл.) је ђаво под кожу „Побеснети, изгубити памет”, седети на две столице „подржавати истовремено две супротне стране, бити дволичан, непоуздан, неискрен”, (c)nасти на ниске (танке) гране „доспети у незавидан положај”,правити од комария магариа „преувеличавати нешто” итд.).

Код другог типа јединица једна је компонента носилац фразеолошког значења, ${ }^{12}$ а друга (или друге) јавља се као обавезна компонента фразеологизма (нпр. обећавати брда и долине „обећавати много, оно што се не може остварити”, спавати као топ „спавати чврстим сном”,заљубити се до ушију „потпуно се заљубити”, знати у прсте „знати одлично”). Та друга компонента, употребљена

\footnotetext{
${ }^{9} \mathrm{У}$ средњошколској настави подела се може даље продубљивати - могуће је разврставати грађу према типовима синтагме: именичке синтагме (Ахилова пета, дрвени адвокат, књишки мољаи и сл.), придевске (леп као слика, мршав као грана и сл.) и глаголске (смејати се као луд на брашно, узети на зуби др.).

${ }^{10}$ Овде је, такође, могућа детаљнија анализа (подела на зависне и независне реченице, одређивање врсте зависне реченице и др.).

${ }^{11}$ Приликом осмишљавања овог типа задатка битно је, такође, изабрати типичне примере.

${ }^{12}$ Фунција ове компоненте фразеологизма, према Мршевић-Радовић (1987: 14), може бити интензификација (заљубити се до ушију, ,јако, претерано, преко мере се заљубити”) или квалификација значења (ићи као ћорава мачка „ићи насумице, без циља, лутати, тумарати”).
} 
у свом основном лексичком значењу, не учествује у настанку фразеолошког значења, али подржава његову реализацију. ${ }^{13}$

2.2.1.3. Анализа семантике фразеологизама пружа могућност њихове класификације у одређена поља према глобалном значењу - тзв. фразеосемантичка поља. Другим речима, издвајањем заједничких компоненти значења различитих фразеолошких јединица - оне се могу објединити у својеврсна поља.

У литератури (исп. Вуловић 2015; Пејановић 2006) издвајају се одређена семантичка поља са низовима фразеологизама истог или блиског значења, попут следећих: (а) 'физичке особине' (типа леп као анђео, снажан као бик, ружан као пас, мршав као грана, отанчати као игла); (б) 'психичке и карактерне особине' (душа од човека, човек без кичме, йокондирена иииква и др.); (в) 'способности и вештине' (йливати као секира, говоритии као из књиге, бог и байина); (г)

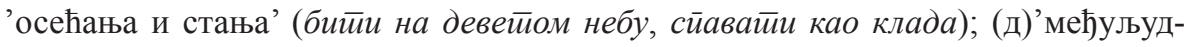
ски односи' (слагати се као рогови у врећи, слагати се као пас и мачка); (ђ) 'друштвени и материјални статус' (живети као бубрег у лоју, сиромашан као црквени миш); (е) 'активности, делатности, понашање'(радити као црнаи (коњ, nac, роб), ићи као мува без главе итд.) и др. Зависно од грађе, та поља склона су модификацијама.

Како би се омогућила практична примена наученог, могу се осмислити задаци у којима се од ученика захтева да из дате групе фразеологизама издвоје оне који припадају одређеном фразеосемантичком пољу (в. вежбања 19 и 20).

\subsection{2. ДОДАТНА НАСТАВА}

Ужа фразеолошка тема, коју би требало обрадити на часовима додатне средњошколске наставе, тиче се механизама помоћу којих настају значења фразеологизама. За потребе ове наставне јединице довољно је представити два честа механизма -метафору и метонимију, те их сажето илустровати типичним примерима. Циљ ове наставне јединице јесте да се обезбеди њихово препознавање на основу примера. ${ }^{14}$

2.2.2.1. Метафора представља семантичку фигуру која настаје заменом једног појма другим по њиховој заједничкој или сличној особини. Дакле, семантичка транспозиција одвија се на основу сличности (то може бити сличност у обављању неких радњи, сличност положаја, стања, сличност у испољавању понашања и сл.). Основно значење полазне, базне синтагме постаје експресивни назив за неку другу појаву или предмет, који су у вези са значењем полазне син-

\footnotetext{
${ }^{13}$ Према процени наставника, семантичкој теми може се придружити још једна подела на два типа фразеологизама: (а) поредбени (мршав као грана, леп као лутка, слагати се као пас и мачка и др.) и (б) непоредбени фразеологизми (уништити до корена, обећавати златна брда и долине и сл.).

${ }^{14}$ На такмичењима су се јављала и питања у којима се захтев односио на препознавање механизма настанка значења конкретног фразеологизма (СЈКТ2 2008: 263):

Значење фразеологизма спустити нос, који значи „снуждити се, покуњити се”, резултат је:

а) метафоре; б) метонимије; в) синонимије; г) антонимије.

Заокружи слово испред тачног одговора.
} 
тагме. На пример, фразеологизам сатерати некога у мишју рупу значи „довести некога у незгодан положај”, а фразеологизам дићи све четири увис „ленствовати, излежавати се". Код ових фразеологизама може се приметити сличност између именованог стања, радње и онога што тај фразеологизам означава (Мршевић-Радовић 1987: 35-36).

2.2.2.2. Метонимија, такође, представља семантичку фигуру која настаје заменом једног појма другим, али се та замена, за разлику од метафоре, заснива на конкретној логичкој вези (Мршевић-Радовић 1987: 36-41). Тако, на пример, имамо фразеологизме попут хватати се за главу са значењем „бити у тешком, безизлазном положају, очајавати”, или дићи нос са значењем „постати охол, уобразити се". ${ }^{15}$ Оно што се на први поглед запажа јесте да код ове групе фразеологизама постоји предметно-логичка веза између онога што је исказано и онога што тај фразеологизам значи. Другим речима, то су фразеологизми у којима се цела слика тумачи као знак за разумевање неке појаве којој је изворна слика саставни део (исп. Драгићевић 2010: 160-163).

\subsection{3. ВЕЖБАЊА}

9. Разврстај следеће фразеологизме према структури:

забадати нос у нечији посао, на крај света, око соколово, бити луд за неким, пасти на ниске гране, млад као роса у подне, у исти мах, црна овца, фали му (јој и сл.) даска у глави, лукав као лисица, кад на врби роди грожђе, миран као бубица, пала му (јој и сл.) је секира (кашика и сл.) у мед

10. Разврстај синтагматске фразеологизме према врсти синтагме:

камен спотицања, стар као Библија, одвојити жито од кукоља, књишки мољац, бити између две ватре, мршав као глиста, дрвени адвокат, слободан као птица (на грани), веран као пас, мрка капа

11. Анализирај структуру следећих предлошко-падежних фразеологизама (по моделу предлог + падеж):

у исти мах

на први поглед

на првом месту

испод жита од Кулина бана

у крајњој линији

до миле воље

у духу времена

12. Допуни следеће фразеологизме:

ни по бабу (ни по стричевима $)^{16}$

превести преко (жедна/жедног, воде)

бежати главом (без обзира)

${ }^{15}$ Ученицима се може указати и на то да се у оваквих фразеологизмима, чије је значење настало метонимијским преносом, често описује неки гест, те се у њиховом саставу неретко јављају лексеме које означавају делове тела.

${ }^{16}$ У заградама су дата решења постављених задатака. 


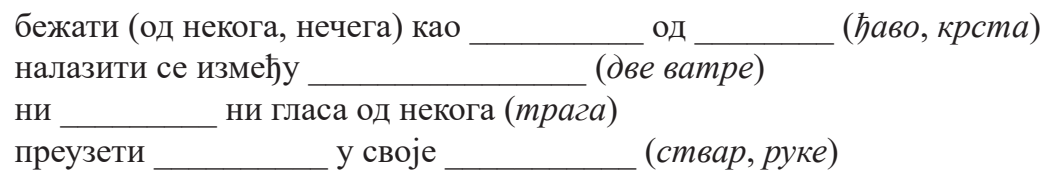

13. Ако се неко с неким игра мачке и миша, он се: ${ }^{17}$

(a) свађа с њим;

(б) поиграва с неким, ради с њим шта жели;

(в) такмичи, бори за надмоћ.

14. Када неко падне с коња на магарияа, он је:
(a) тешко пао, повредио се при паду;
(б) доспео у гори положај;
(в) изашао из јавног живота.

15. Ако је неко доспео из јаме у рупу, он је:
(a) повукао се, сакрио се;
(б) напредовао у послу;
(в) из лоше ситуације дошао у још гору.

16. Ако неко некоме очита буквищу, он га је:
(a) научио нечему;
(б) прекорио;
(в) излечио,

17. Када кажемо да је неко некога дочекао на нож, то значи:

(a) да је неко некога оштро напао, осудио;

(б) да је неко некога убо;

(в) да је неко некоме објавио рат, борбу;

18. Ако неко некога очекује као озебао сунце, онда он очекује:
(a) јер му је хладно;
(б) са много чежње;
(в) са много воље.

\footnotetext{
${ }^{17}$ Међу такмичарским задацима за 8 . разред основне школе јављају се и они који од ученика траже да препознају значење датог фразеологизма (в. СЈКТ2 2008: 135):

У примеру Увек је радио испод житаподвучени израз значи:

а) на брзину, непромишљено

б) кришом, потајно

в) у подруму

г) у руднику

Заокружи слово испред тачног одговора.

Задаци са сличним захтевима јављају се и у такмичарским задацима за средњошколце (исп. CJKT2 2008: 262-263).
} 
19. Подвуци фразеологизам који се односи на друштвени и материјални статус човека:

ићи као ћорава мачка, живети као бубрег у лоју, седети на све столице, пасти у ватру

20. Међу фразеологизмима подвуци оне које се односе на физичке особине човека:

спавати као клада, попети се некоме на главу, мршав као грана, седети скрштених руку, мрка капа, везати некоме руке и ноге, леп као слика, дрвени адвокат

\section{3. Речници у настави фразеологије ${ }^{18}$}

\subsection{1. ТЕОРИЈСКИ ДЕО}

2.3.1.1. Најзначајнији описни речници српског језика - Речник СAHУ, Речник $M C$ и $P C J$ - показују се веома подесним у настави српског језика и књижевности, иако им се не прибегава често. ${ }^{19}$ Уколико се речници користе у настави, то су обично двојезични речници, за потребе превођења. Међутим, једнојезични речници српског језика обично су запостављени у школству, што због наставних планова и програма који их не укључују, што због њихове недоступности у многим школским библиотекама (Милосављевић 2020а: у штампи).

2.3.1.2. Једнојезични речници српског језика могу се користити као приручно средство у активној и функционалној настави језика, ${ }^{20}$ а између осталог, и на наставним јединицама посвећеним усвајању фразеолошких садржаја. Најбоље је речнике користити као лингвометодичке текстове, како би ученици кроз захтеве усвајали и знања о организацији речничких чланака у речницима српског језика, као и о начинима представљања лексичких и граматичких информација у њима (в. вежбања 21 и 22). На тај начин се ученици упознају и са различитим врстама и наменама речника, чиме се оспособљавају за њихово осмишљено и делотворно даље коришћење. Упућивање ученика на коришћење речника требало би да буде један од циљева у процесу институционалног развијања језичке културе, почев од виших разреда основне школе па до академске наставе (исп. Прћић 2008: 21-22; Милосављевић 2019: 188-192).

Речнички чланак може се користити за уочавање и увежбавање једне одређене лексичке појаве (попут полисемије или језичких механизама полисе-

\footnotetext{
${ }^{18} \mathrm{O}$ могућностима примене речника у настави лексикологије за студенте, као и о вежбањима кроз која се та знања савладавају и продубљују в. Милосављевић $2020 б$ (у штампи).

${ }^{19}$ Више о развијању речничке културе у академској настави, те о могућностима примене речничке литературе в. Милосављевић 2019 (181-194). За наставнике може бити користан још један рад исте ауторке у којем се путем упитника испитују студентска (пред)знања о речницима, о типовима информација које се могу наћи у једнојезичним речницима српског језика, као и навике у вези с коришћењем речника (в. Милосављевић 2020а: у штампи).

${ }^{20}$ Аутори С. Новокмет и М. Богдановић (2015: 176-184) показују како се Речник САНУ може користити у настави књижевности, као и у настави историје језика, лексикологије, акцентологије и морфологије.
} 
мије, затим парадигматских лексичких односа попут синонимије, антонимије, хомонимије и хипонимије, употребне и стилске вредности лексике, колокација, израза, као и фразеологизама). Такође, речнички чланак може послужити као лингвометодички текст за увежбавање више лексичких појава, уколико се оне прожимају. Будући да сваки речнички чланак обједињује различите информације о датој одредници, системска анализа чланка је у већини случајева неизбежна. Таквом анализом текста могу се савладати не само одређене лексичке појаве, већ се на тај начин ученици увежбавају да читају речник и да помно прате све забележене информације (Милосављевић 2020б: у штампи).

2.3.1.3. Усвајање фразеолошких садржаја може бити подстакнуто и коришћењем специјализованих, фразеолошких речника у настави (в. Матешић 1982; Оташевић 2007; Оташевић 2012), који пружају обиље грађе, те могу послужити као основа за уобличавање наставних јединица и задатака, али и као штиво за ученике. Посебно занимљива и, у дидактичком погледу, корисна може бити књига М. Шипке (2013), у којој је сваком фразеологизму посвећен краћи текст, са објашњењима њиховог значења и порекла (в. вежбање 21).

\subsection{2. ВЕЖБАҢА}

21. На основу следећег текста препознај о ком је фразеологизму реч:

Овај израз значи да се неко бави нечим узалудним, бескорисним. Порекло овог фразеологизма крије се у давно минулим временима и у активностима које се за њих везују. У стара времена жито се врхло на два начина - помоћу коња и млаћењем. Вршидба без коња подразумевала је да се рукама млатило пожњевено жито, чиме се одвајало зрневље од класја. Тај посао имао је свој смисао и своју сврху, јер се на тај начин добијало чисто зрно. Међутим, млатити по празном, већ овршеном снопљу, од којег је остала само слама без зрневља, није имало никаквог смисла.

Реч је о фразеологизму млатити празну сламу (Шипка 2013: 228-230). ${ }^{21}$

22. Међу примерима пронађи фразеологизам и одреди његово значење:

ймӯћан и иму́ћан, -ћна, -ћно који има доста материјалних добара, новца и сл., добростојећи, богат. - Великаш сам могућан и имућан (Шен. А. 18, 20). То је био човек доста имућан: ни богат ни сиромах (Весел. 7, 87).[...] Дошао је имућан. Има одела и другог добра - тушта и тма (Моск. 3,106$)$. Што су задруге напредније, то је и ... општина имућнија и јача (Миодр. 3, 370).(РСАНУ)

23. Међу изразима одреднице појас издвоји фразеологизам:

по̀jа̄c м (лок. поја́су и пӧја̄су); исп. пас 1. оно чиме ce onacyje, nomnacyje odeћa y cmpyку (каиш, опасач и сл.). - Опасао се широким стамболским појасом. Андр. И. За појасом им ручне гранате.Јонке. [...]

Изр. биљни, вегетациони биљни покривач који се мења према висинским разликама над морем. црвени знак вишег ирквеног чина у католичкој и православној цркви. до појаса (клањати се) савијати тело готово под правим углом, као знак покорности, потчињености.[...] за спаса́ва̄ње пом. направа од непропустљивог платна, испуњена плутом, која се

\footnotetext{
${ }^{21}$ Текст је дат у редукованом виду због ограниченог обима овог рада.
} 
навуче на тело ради одржавања на повриини воде.[...] стезати се у појасу мање јести због штедюе или сиромаштва; исп. стезати каиш (уз каиш изр.). - У таквој невољи [за неродице], и Кушмељ и Осињача и Кушмељићи стегли би се у појасу. Мат.

2.4. Могућности укључивања фразеолошке тематике у друге наставне јединице

2.4.1. Иако је могуће оформити читав наставни блок посвећен фразеолошкој тематици, теме поменуте кроз рад није неопходно обрађивати засебно и изоловано од других садржаја. Фразеологизми се, упркос посебном дидактичком приступу који захтевају, у наставни процес могу укључивати по принципу пригодности (исп. Чабрић-Чича 2014: 219; Ђукић 2019: 243). Овај принцип подразумева да се фразеолошке јединице тумаче онда када се нађу у тексту (када је реч о обради књижевних дела) или када се јави било који други повод за њихово укључивање у наставну јединицу. 22

2.4.2. Представљање особености фразеологизама и упознавање са овим јединицама може се прикључити, осим часовима књижевности, и часовима граматике (в. т. 2.2.1.1), часовима посвећеним полисемији лексема (в. т. 2.2.1.2, 2.2.1.3), али и часовима на којима се говори о парадигматским лексичким односима - синонимији и антонимији. ${ }^{23}$ Поред наведеног, наставне јединице са стилистичким темама, у оквиру којих је препоручљиво укључивати рад на текстовима различитих стилова (између осталог, и новинарског), могу се комбиновати са фразеолошком тематиком, посебно када је реч о разграничењу различитих типова устаљених израза (в. 2.1.2).

2.4.3. Континуирана заступљеност ужих фразеолошких тема у оквиру других (и различитих) наставних јединица, као и краћих фразеолошких вежби у наставној пракси доприноси, како наводи Ђукић (2019: 243), како циљевима репродуктивног типа (односно, утиче се на то да ученици примете и запамте основне карактеристике фразеологизама), тако и циљевима продуктивног типа (односно, да фразеолошке јединице постану део активног лексичког фонда ученика).

${ }^{22}$ Повод за укључивање фразеолошке тематике у наставу може бити и појединачна лексема, поготово она која је богато заступљена у фразеолошкој грађи (нпр. рука, глава, око, нога, вода). У речничким чланцима тих лексема забележено је обиље фразеологизама, којима се може приступати према различитим критеријумима.

${ }^{23}$ Може се запазити да се и фразеологизми, попут засебних лексема, могу наћи у синонимском или антонимском односу: (1) обрати зелен бостан : наћи се у небраном грожђу; млатити празну сламу : хватати зјале : красти богу дане; или (2) ситна риба : крупна зверка; леп као слика : ружан као пас итд. У вези са тим, могу се осмислити задаци у којима би се захтевало да се повежу синоними или антоними међу фразеологизмима или да се напише дати синоним, односно антоним наведеног фразеологизма. 


\section{3. Закључак}

Кроз рад је показано на које се све начине фразеолошка тематика може укључивати у наставне садржаје у основношколском и средњошколском образовању. Представљено је широко поље фразеолошких тема, које се може искористити за формирање читавог наставног блока посвећеног фразеологији српског језика, али и за њено повезивање са другим наставним јединицама, попут оних посвећених граматици и лексикологији, те наставним јединицама посвећених стилистици или обради књижевних дела. Фразеолошка настава може обезбедити и (веома корисно) упознавање ученика са речничком литературом српског језика.

У раду су представљени различити типови задатака који прате издвојене фразеолошке теме - упознавање са њиховим основним карактеристикама, структурне и семантичке особености фразеологизама, као и могућности употребе речничке литературе у настави фразеологије српског језика. Циљ представљених задатака је да обезбеде што функционалнију обраду датих фразеолошких сегмената, али и да помогну ученицима да ваљано савладају теоријски представљено наставно градиво.

Пошто се основна знања, како језичка тако и остала, стичу у школи, важан је задатак наставника српског језика да, водећи рачуна о специфичностима сваког облика наставе језика и о њиховим садржајима и циљевима, све видове наставе, с великом пажњом, лингвистички (и социолингвистички) уобличи. Управо кроз систематизовано увођење фразеолошке тематике у наставу у основној и средњој школи наставници имају доста простора за (преко потребно) подстицање развијања језичке и речничке културе ученика. Циљ оваквих наставних јединица је, дакле, вишеструк. У првом реду, циљ је да се обезбеди примерено владање фразеолошким јединицама матерњег језика, али и, с друге стране, да се поспеши богаћење лексичког фонда ученика, као и укупне говорне културе.

\section{ИЗВОРИ}

Матешић 1982: J. Matešić, Frazeološki rječnik hrvatskoga ili sprskog jezika, Zagreb: Školska knjiga.

Оташевић 2007: Ђ. Оташевић, Мали српски фразеолошки речник, Нови Сад: Прометеј.

Оташевић 2012: Ђ. Оташевић, Фразеолошки речник српског језика, Нови Сад: Прометеј.

PMC: Речник српскохрватскога књижевног језика, I-VI, Нови Сад: Матица српска, 1967-1976.

РСАНУ: Речник српскохрватског књижевног и народног језика, I-XX, Београд: Српска академија наука и уметности, Институт за српски језик САНУ, 1959-.

2PCJ: Речник српскога језика, Нови Сад: Матица српска, 2011. 
СЈКТ2 2008: Српски језик кроз тестове 2, Босиљка Милић (прир.), Београд: Друштво за српски језик и књижевност Србије.

Шипка 72013: М. Шипка, Зашто се каже?, Нови Сад: Прометеј.

\section{ЛИТЕРАТУРА}

Вуловић 2015: Н. Вуловић, Српска фразеологија и религија, Београд: Институт за српски језик САНУ.

Драгићевић 2010: Р. Драгићевић, Лексикологија српског језика, Београд: Завод за уџбенике.

Ђукић 2017: М. Ђукић, Фразеологија у тестовима из српског језика са такмичења за средњу школу, Кюижевност и језик LXIV/1-2, 233-246.

Милосављевић 2019: Б. Милосављевић, Развијање речничке културе у академској настави, Књижевност и језик LXVI/1, 181-194.

Милосављевић 2020а: Б. Милосављевић, Речници и њихова сврха у образовању-из угла будућих учитеља, у: Зорана Опачић, Горан Зељић (ур.), Програмске (ре)форме у образовағу и васпитању - изазови и преспективе, Београд: Учитељски факултет, у штампи.

Милосављевић 2020б: Б. Милосављевић, Речнички чланак као текст у настави лексикологије, Иноваџије у настави XXXIII, бр. 4, у штампи.

Мршевић-Радовић 1987: Д. Мршевић-Радовић, Фразеолошке глаголскоименичке синтагме у савременом српскохрватском језику, Београд: Филолошки факултет.

Новокмет, Богдановић 2015: С. Новокмет, М. Богдановић, Примена Речника САНУ у средњошколској настави српског језика и књижевности, Книжевност и језик LXII/1-2, Београд, 173-187.

Прћић 2008: T. Prćić, Ka savremenim srpskim rečnicima. Novi Sad: Filozofski fakultet, prvo, elekronsko izdanje. Dostupno na: http://digitalna.ff.uns.ac.rs/sadrzaj/2018/978-86-6065-454-2[преузето 4. 9. 2020].

Станојчић, Поповић 2011: Ж. Станојчић, Љ. Поповић, Граматика српскога језика, Београд: Завод за уџбенике и наставна средства.

Чабрић-Чича 2014: А. Чабрић-Чича, Обрада фразеологизама у настави њемачког језика, Методички видици, год. 5, бр. 5, Нови Сад: Филозофски факултет Универзитета у Новом Саду, 213-229. 
Bojana D. Todić Sanković

\title{
PHRASEOLOGY IN SERBIAN LANGUAGE TEACHING: THE POSSIBILITIES OF A WIDER APPLICATION
}

\begin{abstract}
Summary
The paper deals with the possibilities of a wider application of phraseological content in Serbian language teaching in primary and secondary schools. The main goal of our work is to point out its various domains, which can further be designed as smaller teaching units. It also presents the appropriate types of tasks, which follow every individual unit.Our research shows that phraseological topics can be included in various teaching units (such as teaching literature, stylistics, grammar, lexicology, etc.). We, also, point out the possibility of forming an entire teaching block dedicated to the phraseology of Serbian language.

Keywords: phraseology, Serbian language, Serbian language teaching, primary and secondary schools, the application of phraseological content in Serbian language teaching.
\end{abstract}

